\title{
The difference a day makes
}

Julia Millinship, MBBS, DRCOG, MFFP, SCMO in Family Planning, North Staffordshire Hospital NHS Trust, Bedford House Clinic, Havelock Place, Stoke on Trent, ST1 4PR, UK.

(Accepted $2^{\text {nd }}$ February 2001)

The Journal of Family Planning and Reproductive Health Care 2001: 27(4): 222-223

\begin{abstract}
A patient attended a clinic requesting Depo Provera after emergency contraception. She gave a history of normal menstruation, but a pregnancy test proved positive. Subsequently an ectopic pregnancy was diagnosed.
\end{abstract}

\section{Case report}

A young nulliparous woman of 20 attended a local family planning clinic requesting Depo Provera. The history was taken by the family planning nurse, who was told that this was the third day of her period. She had been given PC4 by her GP 3 weeks previously (Day 10 of her cycle). This bleed was normal for her, and on time. There was no past history of any medical problems and the only surgery she had had was an appendicectomy. I spoke to her and agreed that the injectable would be a suitable method of contraception, especially as she had had it previously with no problems. She was a little taken aback when I suggested a pregnancy test before giving her the injection. I explained that this was a precaution to make sure the emergency contraception had worked.

The test was positive. I now realised that further consultation would not be easy. My patient was amazed and could not believe it. She called her boyfriend in and there was an uncomfortable silence. They were both very upset and when finally she spoke she said she needed time to think about the situation. An appointment was made for the next day in a different clinic. She wanted the test repeated and she decided to bring an early morning specimen of urine.

She arrived for the appointment on time with her boyfriend. As she came into the room, I noticed how unwell she looked. She was very pale and walked with some difficulty.

I explained that the repeat pregnancy test was positive and she told me that she had got used to the idea and wanted to keep the baby. She went on to say that her bleeding had become heavier and that she had had right sided abdominal pain since 6:00 am. She had been unable to eat anything and felt very sick. I suggested an examination.

Her blood pressure and pulse were normal. Abdominally, she was very tender in the right iliac fossa with guarding. She had an appendicectomy scar. It was impossible to do a vaginal examination due to the pain. I felt that she had a right ectopic pregnancy.

She got off the couch and I proceeded to explain what I thought was happening to her and that she needed to be admitted to hospital.

She was operated on that afternoon and a right salpingectomy was performed.

\section{Discussion}

Papers published have reported ectopic pregnancies after diethylstilboestrol, ${ }^{1}$ high dose oestrogen ${ }^{2}$ and after the Yuzpe method. ${ }^{3}$ More recently, ectopics have been reported after mifepristone. ${ }^{4,5}$ My concern is that perhaps there are more cases as yet unreported, and also, that with the increase in Chlamydia infection it could be a more common event. A paper published in the BMJ showed that by reducing the rate of chlamydia infection in young people the incidence of ectopics was reduced. ${ }^{6}$

I think that, with the increasing use of emergency contraception (mainly Levonelle which is also available from pharmacies), it is important the patient is counselled to see a doctor for follow-up if she has irregular bleeding or pain.

References

Smythe A, Underwood P. Ectopic pregnancy after postcoital diethylstilboestrol. America Journal of Obstetrics and Gynecology 1975; 121: 284-285.

Morris J.M, Van Wagenen G. Interception: The use of postovulatory estrogens to preven implantation. American Journal of Obstetrics and Gynecology 1973; 115: 101-106.

Kubba A, Guillebay J. Case of ectic pregnancy after postcoital contraception with ethinyloestradiol and levornorgestrel. BMJ 1983; 287: 1343-1344.

with anordrin for emergency contraception. A randomized multicentre trial. 1998. Unpublished work.

5 World Health Organisation. WHO Task Force on postovulatory methods of fertility regulation. Comparison of three single doses of mifepristone as emergency contraception. A randomized trial. Lancet 1999; 353: 697-702.

6 Egger M, Low N, Davey Smith G, et al. Screening for the chlamydial infections and the risk of ectopic pregnancy in a county in Sweden: ecological analysis. BMJ 1998; 361: 1776-1780. 